The International Journal of
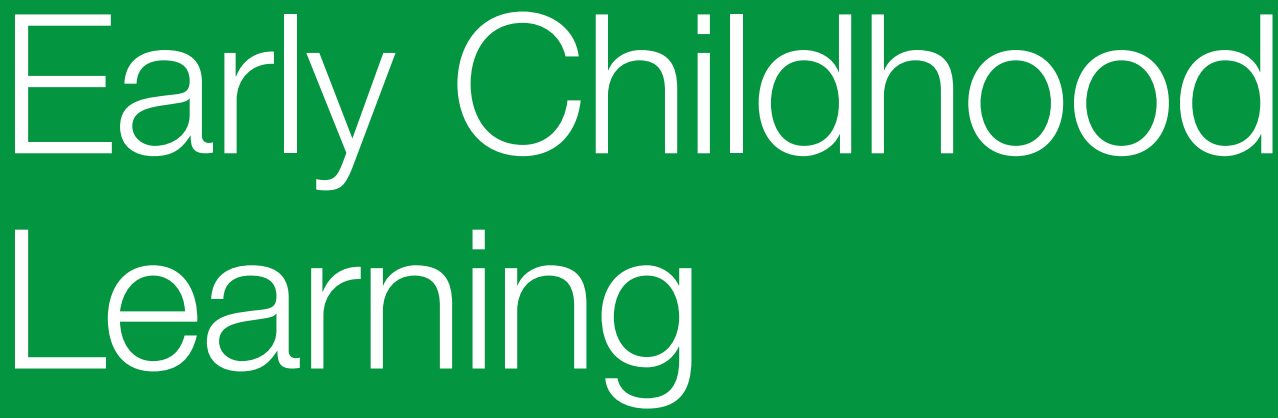

The Arts for Reading and Spelling in Different Educational Contexts 


\section{THE INTERNATIONAL JOURNAL OF EARLY CHILDHOOD LEARNING \\ https://thelearner.com \\ ISSN: $2327-7939$ (Print) \\ ISSN: 2327-8722 (Online) \\ https://doi.org/10.18848/2327-7939/CGP (Journal)}

First published by Common Ground Research Networks in 2019 University of Illinois Research Park

2001 South First Street, Suite 202

Champaign, IL 61820 USA

$\mathrm{Ph}:+1-217-328-0405$

https://cgnetworks.org

The International Journal of Early Childhood Learning is a peer-reviewed, scholarly journal.

\section{COPYRIGHT}

(C) 2019 (individual papers), the author(s)

(C) 2019 (selection and editorial matter)

Common Ground Research Networks

\section{(a) $(1) \odot$}

Some Rights Reserved.

Public Licensed Material: Available under the terms and conditions of the Creative Commons Attribution-NonCommercial-NoDerivatives 4.0 International Public License (CC BY-NC-ND 4.0). The use of this material is permitted for non-commercial use provided the creator(s) and publisher receive attribution. No derivatives of this version are permitted. Official terms of this public license apply as indicated here: https://creativecommons.org/licenses/by-nc-nd/4.0/legalcode

\section{Crossref}

\section{EDITORS}

Bill Cope, University of Illinois at Urbana-Champaign, USA Mary Kalantzis, University of Illinois at Urbana-Champaign, USA José Luis Ortega, University of Granada, Spain

\section{HEAD OF JOURNAL PRODUCTION}

McCall Macomber, Common Ground Research Networks, USA

\section{EDITORIAL ASSISTANT}

Crystal Lasky Robinson, Common Ground Research Networks, USA

\section{ADVISORY BOARD}

The Learner Research Network recognizes the contribution of many in the evolution of the Research Network. The principal role of the Advisory Board has been, and is, to drive the overall intellectual direction of the Research Network. A full list of members can be found at https://thelearner.com/about/advisory-board.

\section{PEER REVIEW}

Articles published in The International Journal of Early Childhood Learning are peer reviewed using a two-way anonymous peer review model. Reviewers are active participants of The Learner Research Network or a thematically related Research Network. The publisher, editors, reviewers, and authors all agree upon the following standards of expected ethical behavior, which are based on the Committee on Publication Ethics (COPE) Core Practices. More information can be found at: https://thelearner.com/journals/model.

\section{ARTICLE SUBMISSION}

The International Journal of Early Childhood Learning publishes biannually (June, December). To find out more about the submission process, please visit https://thelearner.com/journals/call-for-papers.

\section{ABSTRACTING AND INDEXING}

For a full list of databases in which this journal is indexed, please visit https://thelearner.com/journals/collection.

\section{RESEARCH NETWORK MEMBERSHIP}

Authors in The International Journal of Early Childhood Learning are members of The Learner Research Network or a thematically related Research Network. Members receive access to journal content. To find out more, visit https://thelearner.com/about/become-a-member.

\section{SUBSCRIPTIONS}

The International Journal of Early Childhood Learning is available in electronic and print formats. Subscribe to gain access to content from the current year and the entire backlist. Contact us at support@cgnetworks.org.

\section{ORDERING}

Single articles and issues are available from the journal bookstore at https://cgscholar.com/bookstore.

\section{HYBRID OPEN ACCESS}

The International Journal of Early Childhood Learning is Hybrid Open Access, meaning authors can choose to make their articles open access. This allows their work to reach an even wider audience, broadening the dissemination of their research. To find out more, please visit https://thelearner.com/journals/hybrid-open-access.

\section{DISCLAIMER}

The authors, editors, and publisher will not accept any legal responsibility for any errors or omissions that may have been made in this publication. The publisher makes no warranty, express or implied, with respect to the material contained herein. 


\title{
The Arts for Reading and Spelling in Different Educational Contexts
}

\author{
Paddy Carson, ${ }^{1}$ James Cook University, Australia
}

Abstract: This research focuses on the delivery of a multi-sensory literacy program incorporating an arts-based reading and spelling approach delivered in two different educational settings. As well as the development of self-regulation tools by the children. The first setting is a traditional kindergarten, where it was provided as a supplement to reading instruction for a small group of children. The second setting was a small group of home-schooling parents and children. This action research focused on similarities and differences of working with these two groups; and how program delivery was adapted and changed to meet the learning needs and styles of the children.

Keywords: Symbol Mastery, Literacy, Letter Name Recognition, Creativity, Autoethnography

\section{Introduction}

$\mathrm{T}$ This research focuses on the researchers experiences in providing multi-sensory literacy experiences within two different educational settings: two traditional kindergarten classrooms and a small homeschooling group made up of three families. The researcher provided stories, movement activities as well as clay experiences, which were based on the ideas of Ron Davis, in which the researcher is trained. One of the strategies used is Symbol Mastery, which uses clay and the learner's imagination and creativity to create three-dimensional clay representations of a word and its existing definition. These activities had the potential to benefit each group.

\section{Background to the Study}

In classrooms there are often some children who struggle with mastering and understanding phonics and other literacy skills (Graham et al. 2008). These are frequently non-verbal conceptual thinkers who think and manipulate images in three dimensions; rather than primarily with sounds (Davis and Braun 1994, 2010; Silverman 2002; West 1991).

Children in the traditional school-based kindergarten programs (groups KA and KB) attended a school with the second lowest literacy outcomes in the city (Fraser Institute 2017). The teachers used a variety of approaches including videos, smart boards, movements for large muscles (including movements to create the letters in space) (Hill-Clarke and Robinson 2002), music in the form of rhymes and the alphabet song; fine muscle activities included tracing letters in different mediums such as shaving cream and "goop" (cornstarch and water mix )(Kid Sense Child Development 2018).

In this study imagination and creativity were engaged when the children created the models which represent the definitions of words and concepts which could then be observed by others (Ambrose and Cheong 2011; Carson and Sorin 2016). In this research, storytelling and movement were included to help illustrate a letters' appearance (Reig and Kelli 2009; Woods, Reeves, and Whitehouse 2018), while clay was used to create both the written symbol and visual definition of a word (Davis and Braun 1997, 2010). As Davis and Braun (2010, 65) observe,

\footnotetext{
${ }^{1}$ Corresponding Author: Patricia Carson, P. O. Box 6811 1/14 Mc Gregor Road, College of Arts, Society and Education, James Cook University, Cairns Campus, Smithfield, Queensland, 4870, Australia. email: Patricia.Carson@my.jcu.edu.au
}

The International Journal of Early Childhood Learning

Volume 26, Issue 1, 2019, https://thelearner.com

(C) Common Ground Research Networks, Paddy Carson,

Some Rights Reserved, (CC BY-NC-ND 4.0).

Permissions: cgscholar.com/cg_support

ISSN: 2327-7939 (Print), ISSN: 2327-8722 (Online)

https://doi.org/10.18848/2327-7939/CGP/v26i01/27-45 (Article) 
"The creative process and the learning process, if not identical, are so closely related that they are inseparable."

\section{Literature Review}

This literature review is conducted in two parts. Part one looks at the arts and creativity in learning; part two looks at the researchers' learning (autoethnography).

\section{Arts and Creativity}

Imagination is a useful aid to learning; by involving learners in using their creativity and imagination, they are building, creating, and recreating their world to aid understanding (Healy 2008; Davis and Braun 1997, 2010). An example of this learning is demonstrated in the Waldorf School curriculum, which is based on Steiner's belief that reading and writing can be achieved through art including movement (Burnett 2007; Woodard 2005). These activities support the child's natural curiosity and belief that children learn faster and more thoroughly when interested (Shank 2016; Ambrose and Cheong 2011; Davis and Braun 1997; Wall 2006). Wall (2006), in his study, found that the child's natural curiosity could be linked to art and understanding, which helped with learning. Another example of this creativity and art-based learning is found in the Reggio Amelia philosophy, which endorses the idea that all children are born creative but lose this ability when put into formal educational settings. Reggio Amelia builds on the learner's creativity and desire to learn and supports the idea that art experiences can be beneficial for learning (Cutcher 2013; Dewey 1986; Thompson 1982; Tomascoff 2004; Wall 2006).

Using creativity involves the learners on an intellectual level by learning the letter name and appearance (Treiman 1993; Treiman and Rodriguez 1999; Roberts 2003), then developing an understanding of a word's existing meaning or the concept it represents (Davis and Braun 1997, 2010; Kalantzis and Cope 2005; Phillips and Feng 2012; Silverman 2002; Warwick 2005).

\section{Autoethnography}

Wall (2006) suggests autoethnography as an approach that can help the researcher utilize experience to extend their understanding (Chang 2016; Ngunjiri, Hernandez, and Chang 2010; Sanders, Parsons, and Thomas 2015). This is a method of discovery made through self-reflection including observations on how an individual researcher reacts and adapts to different experiences and memories (epiphany) (Ellis, Adams, and Bochner 2011). Thus, resulting in research that is more personal than clinical.

The researcher's focus was on the delivery of a multi-sensory literacy program using different forms of art to aid learning such as storytelling, movement, and creating clay representations of letters, words, and definitions. As well as observing if these activities aided learning efficiency and participation (Kental, Dobson, and Dobson 2007).

\section{Methodology}

\section{The Research Method}

The research methods used within this project were action research and authoethnography. Action research is the research process in which the researcher looks at different ways of adapting and developing approaches which built on preexisting multi-sensory models. The goals were to develop a new understanding of which approaches and presentation of activities helped produce the best learning outcomes for the two different groups and to use an autoethnographic approach, whereby the researcher looked at the process of delivery and adaption of activities and steps to make the program more effective. As well as looking at the learning and epiphanies (if 
any) of the researcher. As McNiff and Whitehead (2011) observe, this practice has the potential of being an agent of change for both the learner and researcher.

\section{Data Collection}

Data was collected using the researcher's journal and included reflections on the researcher's and children's discoveries and comments on observations and insights. Notes were recorded on how these observations and epiphanies led to the development of different approaches and adaptations of the already existing program to make it more suitable for the target students, and easier to include more art-based activities within the learning setting. At the school, informal meetings were held with the teachers throughout the year. Here the teachers shared their classroom observations about any changes that had been witnessed which were then recorded in the researcher's journal.

Journal observations and reflections were recorded for the homeschoolers as well. In lieu of meetings with the teachers, informal discussions with the parents were held, and their comments and observations of how their child participated in the activities between the times that we met were recorded. These were then added to the researcher's thoughts and observations. Results of the journals were compared; innovative ideas and approaches were created based on the information and feedback received. These were then recorded for future reference.

The kindergarten students were identified by their first initial, and if two names started with the same initial a number was allocated, for example: P1, P2. Homeschoolers were identified by their first initial and a "P" was added when referring to the child's parent/guardian/support person. Informed consent was gained from the parent/guardian/support person/s and kindergarten teachers prior to the commencement of the research.

\section{Study Location}

Two kindergarten classes within an inner-city school in Edmonton, Alberta, Canada were offered, each with one full-time teacher and one full-time classroom aide. The homeschoolers' setting was within a private home of one of the attendees. Each child was accompanied by a parent/guardian/support person (usually the mother).

\section{Participants}

The two kindergarten classes included the KA class with a total of twenty-two students and the $\mathrm{KB}$ class with a total of twenty students. Their ages ranged from five-to-six years at the start of the year (September 2017). The five children who participated in the study throughout the year were all girls. They are identified in this study as P1, P2, B1, B2, and S1. The homeschooling group consisted of three children with ages ranging from four-to-ten years at the start of the year (September 2017). All were boys. They are identified in this study by the first initial of their name (Z, I, J). Unlike the kindergarten group, no child's name started with the same letter.

\section{Time Allocated for Each Group}

The researcher spent most of the time (four afternoons a week for a total of two and a half hours. This time was spent with between two and three children each session). From February 2018 to the end of May 2018; the researcher worked one-on-one with each child for varying lengths of time. This ranged from five minutes in February to up to thirty minutes by the end of May. Occasionally, in May, two children would attend together.

Working with the homeschoolers was done less regularly than originally planned due to family commitments and weather. Originally, the homeschoolers meet three times a week for an hour to an hour and a half. After two weeks, this was changed to twice a week for up to two 
hours. After Christmas, meetings occurred at least twice a month for several months from between one and one and a half hours.

\section{Results, Discussion, and Reflections}

\section{Qualitative Data}

Journal observations and reflections were recorded for both the kindergarten students and the homeschoolers as well as records of teacher meetings. Informal discussions with the parents were held and their comments and observations of how their child participated in the activities between the times that we met were recorded.

\section{Kindergarten Group}

Prior to the start of the school year the researcher met with both kindergarten teachers and shared the goals and steps for the year (see Appendix 1). Within the first three weeks of school, both classes were introduced to the idea of a Dial (self-regulation of energy) and Release (selfregulation of releasing tension in the muscles of the body). The Dial was introduced as having three levels of energy. The lowest being labelled "bear," the working level as the "beaver," and high energy as the "wolf." These were all animals the children were familiar with. Release was introduced as "balloon breathing" with first large body movements that had the children moving from a low curled up level and shape to standing tall and wide. This was gradually replaced with a hand movement that raised the hands palms up (breath in) and then lowering the hands with the palms down (breathing out).

They were introduced and shown to the group at "mat time" (group time on a mat/carpet) through demonstrations, stories, and body movements. The researcher created and told stories and designed the movement activities that were incorporated into the stories. The teachers observed the stories and, along with the other room staff, used these ideas to reinforce the use of the tools (Dial, Release) with the children throughout the day. This was to help the children build experience and knowledge of what was appropriate behavior and energy levels for different activities within the classroom and school.

Teachers could refer children to a large Dial that showed the levels being used in visual form. Children were able to show what level they were on by pointing to or naming the animal, while the teacher could reinforce the level expected by referring to the Dial chart.

The role of the "Focus" (also referred to as "orientation") was creating a "state of mind in which mental perceptions agree with the true facts and conditions in the environment" (Davis and Braun 1997, 252). The Focus tool was demonstrated to the five children who continued with the program once they could demonstrate: 1) awareness of their bodies and 2) they could visualize doing activities in their imagination without leaving their chair. This ability to tell the difference between doing things in their imagination and in real time is critical to the success of the focusing tool. This tool, once created, was referred to as "Hands" and had an accompanying gesture of touching the shoulders as a cue.

\section{Homeschooler Group}

The homeschooling group received their three self-regulation tools over two weeks (six sessions). Every second session introduced a new tool to both the children and their parents, reviewed the tool learnt previously, and provided a chance to explore the clay. Part of each session involved time with parents only, explaining the rationale and going over the steps to clarify any misunderstandings, answer any questions, see how the use of the tool/s had gone, and to make any adjustments that were required. This occurred while the children socialized after completing the activities. 
Parents helped with the creation of the Dial both mentally and as an actual dial, which had three levels by providing examples of levels suitable to activities the child was familiar with. For two of the three children, these levels were indicated by colors. The third child indicated the levels using activities they had done that matched the energy level. These Dials were individualized and brought to the next two sessions so that they could be physically set and moved as energy levels changed. This acted as a visual reinforcer of dial levels and appropriate activities. Similar steps to those used in kindergarten for the explanation and creation of Release (balloon breathing) was used with both the children and parents participating.

As with the kindergarten groups, homeschoolers created their "Focus." The researcher walked both the parents and children through the steps to create the tool and gave the same cue the kindergarteners used. Feedback from each session was gathered and recorded. This was mostly provided by the parents who had been observing and helping to build awareness of these tools. At the end of each session where a tool was created, parents were also given a sheet so that they could follow the steps and reinforce them at home between our meetings.

\section{Observations}

\section{Kindergarten Groups}

The children enjoyed hearing and participating in stories that showed how the different levels of the Dial affected behavior. Large muscle movements such as running on the spot or smaller muscle movements like snoring were enjoyed by all. This was shown by the eager participation of most children and requests for further stories. It was observed that some of the boys, when first given the "wolf" label for high-energy outside, would go outside and howl like wolves. This decreased once the novelty wore off. The children demonstrated their knowledge of the Dial levels by making their own Dials. To do this they cut out pictures of the three Dial animals and placed them in the correct order. This created an opportunity for the teachers and me to observe and help where needed to put the animals in the correct order and talk about appropriate activities for each setting and how the energy level can be changed depending on the activity.

A longer time was needed for the Release activity which was renamed "balloon breathing." It was first introduced by having the children crouch down and then start to stand to show getting full of air and tense. When standing upright, they then quickly flopped down, to feel the air going out. Once they were used to this, hand movements were added. These gradually replaced the big body movements as they were less intrusive and disruptive.

The teachers reported that they continued to use these tools up until the end of November and found that they worked to help with classroom management. At the end of November priorities in the classroom changed, so the tools were no longer used consistently with all the children. The exception was the five children who the researcher worked with on a mostly individual basis.

For the five learners who continued with the program, it was observed that they used all the tools when playing the card games, doing Koosh, and mastering letters. At first constant prompting was required for all. In mid-April it was observed that B1, B2, would check their tools spontaneously when doing Koosh. They were observed doing the hand gestures that accompanied the tools. Once the letters were completed and more time was spent playing cards B2 and S1 discovered that they were more successful in retaining an image of where the letters were and of finding pairs of letters (both cards with the same letter), when using their tools than when they did not. Using their tools when playing cards with other children enabled B2 and S1 to demonstrate that the tools worked for helping to focus and would lead to a more successful outcome than not using the tools. It was observed that B1, P1, and P2 after observing B2 and S1's success used their tools more frequently. By the end of May, B2 was demonstrating her awareness of when these tools were needed by using them without prompting on many occasions, including outdoors in the playground. 


\section{Homeschooler Group}

After two weeks of using and practicing the Focus tool, all the parents expressed doubt about their child's understanding of what was expected of them when using the "Hands" to focus. At this time the approach was changed. Ideas were given to encourage the child to practice imagining themselves in different situations and then contrast what was real and imaginary. This approach had a positive result for one child $(Z)$ as reported by the parent, who observed that $Z$ had become more proficient at using the "Hands" when looking at letters and words. This was the child who consistently attended and whose parent worked with them during the week to develop competency using the self-regulation tools. No feedback has been received from the other families.

\section{Changes Made}

\section{Kindergarten Groups}

The original intent had been to follow the timeline as set out in Appendix 1. As the reality of working with two challenging kindergarten groups was experienced, this approach was quickly changed. The pace of the program was slowed down (Appendix 2). In consultation with the teachers it was decided to focus on giving all the children their Dial and Release until after the Christmas break and then meet to decide if we would continue to work with all the children or a smaller group.

Familiarity with the Dial and Release process was demonstrated by creating stories that illustrated the skills being used and involved the children's participation through movement. Language was changed to make it more relevant to the children's experiences and to include movement experiences.

The Dial is most often described as having numbers to show the different energy levels. The kindergarten children did not appear to understand the amount the numbers represented but were familiar with the animals selected and how fast or slowly they moved so these were substituted.

The final self-regulation tool, the Focus was not introduced to all the children. In consultation with the teachers it was decided that the researcher would continue to work with a small group of children nominated by the teachers. The criteria for selection was that the teachers felt with some extra time spent on learning, the children would make more progress to reaching their full potential than they were able to achieve without the additional one-on-one experiences.

\section{Homeschooler Group}

After several weeks both the frequency of meeting each week and the length of each session was changed to better accommodate each family's schedules (Appendix 4). With parent/guardian/support person input, it was decided to go from meeting three times a week for an hour and a half to twice a week for an hour and a half. In the middle of January, this changed to once a week for an hour and a half. The location stayed consistent at one parent's home. Sessions were held less regularly than originally planned due to family commitments, illness, and poor weather.

Time was incorporated at the beginning and end of the session for the parents to talk about how they and their child had done with the at home practice, and to discuss any difficulties experienced. At the end of the session a short review of the activity/skill to be practiced and continued at home was conducted. While this was occurring, the children were socializing with each other. If the children had questions or comments, these were usually relayed through the parent/guardian/support person at these times.

The Dial can be represented by having numbers, though as two out of the three children (as reported by the parent/guardian/support person) had no concept of numbers and amounts this was 
not used. Two children chose to use colors to indicate different levels of activity ( $Z$ and I), with the third linking their energy level to images of activities they liked to do. This made the Dial more individual and relevant for each child, rather than a shared group dial. Though the level names-low, work, high — were the same for all.

The use of the Release/balloon breathing was adapted to reflect individual relaxation exercises and term already being used by the families.

\section{Letter Recognition}

Letter mastery activities commenced in January 2018 and continued until the end of April/early May 2018. Letter mastery included: Creating the letter in clay with the correct number of lines, using the Dial, Release, and Focus (Hands) tools before naming the letter and making a mental image of the letter. As well as naming it with its letter name. This learning was reinforced by playing the card games "pairs" and "neighbors," which are outlined in more detail below.

Before starting to formally make the letters in clay, both groups were given opportunities over several sessions to practice cutting, rolling, and exploring the clay. After two sessions of this unstructured activity the children were encouraged to cut the clay rolls into lines and use them to make different shapes. This activity prepared students for joining the lines to make different letters. The shapes included squares, circles, triangles, semicircles, and wavy lines. These could be considered the equivalent of writing exercises using pencil and paper.

\section{Kindergarten Group}

The kindergarten participants had individual sessions of between ten-and-twenty minutes in duration once or twice a week depending on attendance and willingness to participate.

\section{Homeschooler Group}

The homeschoolers' had a weekly session for three weeks of between one and a half to two hours, with twenty-to-forty minutes devoted to doing letter mastery with both the parent and child. Once the parent felt comfortable with this and the self-regulation process (Dial, Release, Focus), they indicated they were ready to work on their own at home. Follow up was then conducted at times that worked for the families and is gone into more detail further in the research.

\section{Observations}

\section{Kindergarten Group}

These children required more direct instruction, including how to hold the cutter to make cuts for both straight lines, angles, and how to join them together to make points and shapes. The children cut and joined the lines in diverse ways, then added curved pieces to create different random patterns. When they could successfully copy shapes that were basic to making the letters, they moved to exploring the letters. This included: types of lines, shapes, number of lines, and the spaces around and within a letter. Each letter was then made and mastered using a card template as a guide (Figure 1). The letters were then kept in an individual box with the child's name on it. When mastering a letter, the original intent had been to combine both learning the letter name and sound. This activity was to supplement and reinforce the learning that was going on within the classroom. 


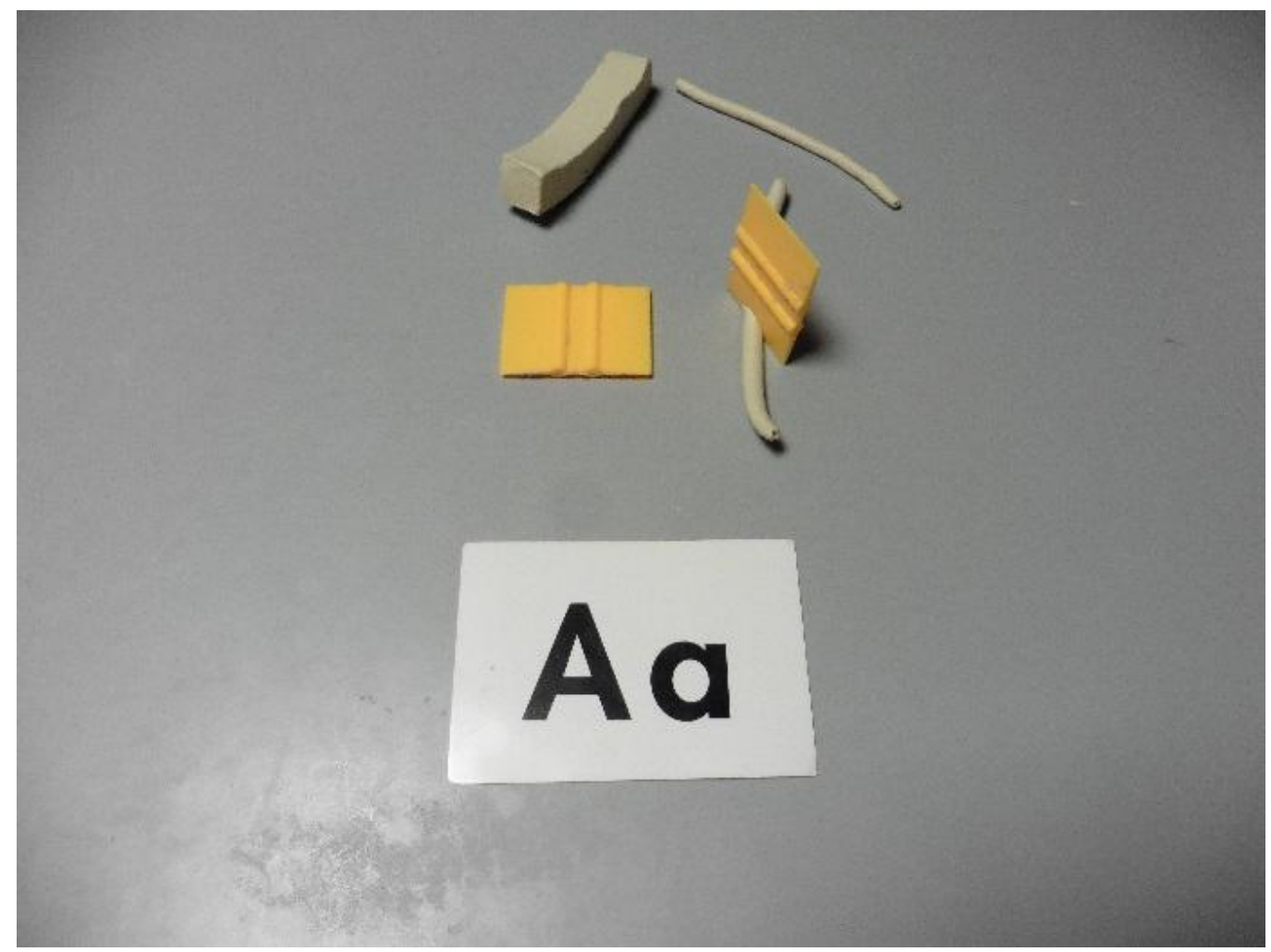

Figure 1: Items Provided for Both the Kindergarten and Homeschooler Groups Source: Carson 2018

\section{Homeschoolers Groups}

As with the kindergarten class, these children were provided opportunities to explore the clay, practice cutting, and making lines and shapes. While doing this, parents were observing, participating, and encouraging their child to do these activities. When it came to make the letters, the researcher demonstrated first to the parents. Then the parents showed the children. The steps included were the same as for the kindergarten class. For the first three sessions of letter making, two-to-three letters were made each session. At the end of the third session parents/guardians/support persons indicated that they would like to continue working on the letters at home and decided that they did not need to meet as frequently. As a result of this decision, a copy of the steps was given to parents/guardians/support persons so that the rest of the letters could be made at home over the coming weeks. Before starting each new session, a review was held, and any questions, concerns, or comments were addressed.

\section{Changes Made}

\section{Kindergarten Groups}

As the researcher moved through the alphabet with the kindergartners, an epiphany occurred with the realization that they had a lack of awareness of how lines and curves looked and felt. The researcher observed that there was a definite improvement in fine muscle ability and awareness of how the shape was constructed particularly when the child used their body to make straight, diagonal, or curved lines. They seemed to enjoy these full body activities, given their willingness to participate and the smiles on their faces. 
Card games were introduced that were variations of the game "concentration." Variations included turning two cards over in each turn to see if they were a pair or not. Each card could be named, if the child wanted to. Otherwise the researcher modelled naming the letter, providing another opportunity to demonstrate the letter name and match it to its appearance. Once all the letters were created the idea of "neighbors" was introduced, whereby the child turned over one card, then looked for one of its neighbors (the card on either side of the turned over card) to make a pair. Similar steps in naming the letters as in the "pairs" game was followed.

\section{Homeschoolers Group}

After making the first six uppercase and lowercase letters with the parent helping the child, they were given the letter templates and clay to continue making the letters at home. This had the added benefit that the child could go at their own pace and the activities could be incorporated into the homeschooling activities without the stress of having to travel in poor weather or miss a session due to another family member's illness. The card games used for the kindergarten children were shared with the families as another letter recognition activity.

\section{Symbol Mastery}

Symbol Mastery is a process of creating a clay image of the already existing definition for a target word and spelling the word in clay; resulting in a better understanding of what the word represents and how it is spelled. This knowledge helps with recognizing the word in different settings such as books, signs and spelling tests.

\section{Observations}

\section{Kindergarten Groups}

Symbol Mastery was first introduced one-on-one so that time could be spent exploring the definition and the model. Children appeared to enjoy the experience of creating the model much more than using the word in sentences! Each child made the same word, using the same definition. It was observed that all the children were more comfortable and willing to answer questions that were either closed or directed to some aspect of the model and definition. An example of this could be, "How is the boy shown to be different from the man?" Questions were designed to draw attention to different aspects of the model and match them to the definition. Prior to commencing creating the definition, a quick way of making models of people and animals was demonstrated, as many words include these. The children made these models their own by individualizing them in a variety of ways, such as B2 putting big eyes on their person to represent "I"- the person who is speaking (Neufedlt 1997).

The kindergarten children who started the Symbol Mastery process appeared to enjoy the creativity of making the models. It was noted that the word went more smoothly if the definitions were broken into parts and each segment talked about before being made.

A discussion was held about how "being talked about" (part of the definition of "he" and "she") could be shown. The first child (B2) to complete Symbol Mastery on a word found this concept hard and was unfamiliar with the idea of a speech bubble. This is the usual way that speech is shown. Resulting from this experience, drawing of stick figures and speech bubbles were introduced so that the child could put a speech bubble onto a figure to show who is talking. This approach was helpful as it was then observed that if the child could attach a speech bubble on paper, they were able to transfer this knowledge to the clay by making a clay speech bubble and attaching it to the model's mouth. Mastery then proceeded quickly. 


\section{Homeschoolers Group}

When Symbol Mastery was introduced to the homeschoolers, one child $(Z)$ watched his parent make the model, but did not make a model himself. A second child (J) did not watch it all. Both parents present worked through the process and were given the steps to work on at home without the child so that they could feel comfortable with the process before working with their child. (The third family was no longer participating.)

One parent (Z's) continued in the next session, while the second (J's) could not continue due to unforeseen circumstances. It was observed that the parent who continued became more comfortable with the process and was able to relate it back to both their own learning and how it could help the child though they found this more challenging than they had expected. The researcher worked for two sessions with this parent. This was how long it took the parent to feel comfortable with and confident enough of their skills to continue working with their child.

Overall the researcher felt there was a lack of the opportunity to observe the parent and child working through the process and to correct any misunderstandings about the how the process should unfold. As a result, there was no information at the time of writing this paper about how successful the participants were with understanding the process and how much they enjoyed or did not enjoy the process.

\section{Changes Made}

\section{Kindergarten Groups}

The children required more concise, simple, direct instructions with modelling for each step. It was observed that with this more detailed step-by-step approach, success was experienced by all participants.

Closed questions were used to draw the child's attention to different aspects of the definition. This was in part due to some of the children's poor language skills as well as the time constraints we worked under in the school as the children had different activities that they participated in.

Words were deliberately chosen that had easy definitions which could be segmented. Each segment was then discussed and created before moving to the next section. All words are included in the Dolch Word List.

\section{Homeschoolers Group}

The researcher worked most closely with parents to show them the steps. More time was spent working one-on-one with the parent who continued to complete the program. The two parents who withdrew for family reasons were given the steps to take home. Both parents had at least one session where we worked together on several words.

\section{My Reflections}

On reviewing the notes and journal entries taken over the year, the researcher became aware of how the program could be adapted and expanded to meet the different learning needs and situations of each group. The main epiphanies are mentioned briefly below and include: storytelling, movement, and creativity in creating the clay definition models for Symbol Mastery. 


\section{Kindergarten Group}

\section{Movement}

Prior to working with the kindergarten children, the researcher had not been aware of how important it was for a child to have a sense of what the different lines (straight, horizontal, diagonal, curved) looked and felt like. To help develop this awareness the children made these shapes using their bodies. This knowledge was then used by their fine muscles when rolling and cutting clay to make the same lines they had experienced with their bodies. The importance of this was demonstrated when the children had difficulties accurately creating straight lines and curved lines, even with step-by-step instruction and practice. The researcher observed after the children had made these lines with their bodies and traced them on the floor, so they could see the shape made, they were more competent in making the shapes in the clay.

\section{Storytelling}

The researcher felt that her own creative skills were expanded. An example was seen in the rediscovery of the enjoyment of creating and telling stories to groups of children. These stories were relevant to the creation and demonstration of the dial and activities appropriate for different dial levels. Stories either involved the researcher acting out different activities and characters either by herself or involving the children. The greater the children's involvement, especially in moving at various levels of energy and speed helped them to gain better understanding and insight into what was being demonstrated.

\section{Creativity in Symbol Mastery}

On observing the hesitancy with which some of the kindergarten children approached the creation of the models, the researcher felt that reassurance needed to be given more consistently throughout the activity as well as to assure them that whatever they made, if it looked representational and they knew what it meant, was acceptable. Using the selected word in sentences helped to stimulate the children's imagination, with the added benefit of enabling the researcher to observe that the correct definition was being used within the sentences made.

Due to the lack of time, (classroom curriculum commitments) the children were not able to spend as long as the researcher would have liked exploring the word in sentences and talking about the parts of the definition. The instruction and discussion tended to be short and directed to how it illustrated that part of the definition.

\section{Homeschoolers Group}

The organization of the homeschooler's session is something that the researcher feels need needs to be reviewed and revised for the next iteration. The organization of the session was haphazard and dependent on parents and children arriving on time and ready to start. It was observed that the non-host parents were frequently late, and they and their children were more interested in socializing at first than starting the program. Perhaps it would be more beneficial if time was allocated before and after the learning activities for socializing or a designated time could be set aside. The session could be held with breaks as required and socializing, again, provided at the sessions end. While the children socialize, discussion and clarification, as well as reviewing any concerns the parents have, could be done. The next session could be held in a more "neutral" setting such as the researcher's office or a neutral, unfamiliar space. This would hopefully put the emphasis on learning first then socializing. Another consideration is that it would make it appear to be a more formal commitment by going to an office or other impartial location, rather than a home. 
Another element that requires review is the collection of feedback about what was being done between our meetings. An option could be to meet weekly with predetermined times to chat or email what had been done at home and to mention any concerns, observations or other feedback that would be recorded by the researcher and kept in a journal. To help with the lack of observations the parents could perhaps be encouraged to take photos to record the images the children made and bring them to each session or email them.

\section{Limitations of the Study}

The researcher was aware of limitations of this study that could have influenced and effected the outcome of the research. These included:

- Inconsistent attendance of all participants due to other commitments and activities, health, and weather, which affected the amount of time spent doing the program.

- The small size of both groups.

- Neither study group was made up of both sexes; nor were they matched for age and sex.

- The homeschooler group had a wide age range, which could have affected continuity and completion of the program.

- The kindergarteners who completed the group were selected from a larger group based on criteria selected by the teachers. While those within the homeschooler group were randomly selected for participation by their parent/guardian/support person's interest in participating. Therefor the samples came from two different approaches and may have influenced the outcomes.

- Undisclosed issues that affected learning, behavior, and participation throughout the program.

- Lack of control groups.

- The researcher being part of the study (the researcher is trained in some of the methods used, as well as using them in private practice). In order to prevent/limit researcher bias from being reflected in the results, all comments and observations made by the parents, children, and teachers were repeated to those making them to check for accuracy and validity of conclusions drawn by the researcher.

- Lack of feedback from the homeschooling parents.

\section{Recommendations}

Recommendations coming from this research include:

- Continuing the informal feedback from teachers and homeschooling parents. Parental contact could take the form of a phone call or email asking for input on how the session went and how the child was doing with the skill being practiced. Input from the teachers could be gathered through ongoing informal meetings. Feedback from both teachers and parents, as well as the researcher's observations, would enable changes and adaptations to be made as required.

- Expanding the number of homeschooler families involved in the research.

- Including more movement and storytelling with both groups. This can be provided by doing it within the session (kindergarten) and/or providing parents with ideas and stories to be done at home (homeschoolers). 
- Conducting a more formal study with pretesting and posttesting for each group in regard to letter and word recognition if appropriate, who would be matched as closely as possible with control groups.

- Information gained from this study could be used in the next iteration involving a larger group of both homeschooler and kindergarten children of similar age, sex, and ethnic background.

\section{Conclusion}

The researcher concluded that this was a learning experience that extended both the children's knowledge of the alphabet and word meanings, as well as the researcher's skills and knowledge, especially in rediscovering the enjoyment of creating stories and sharing them with the children. The researcher's belief in the importance of involving children in their own learning by making them part of the learning experience supports other research that acknowledges how a child's creativity and imagination can be used to augment learning (Phillips and Feng 2012; Silverman 2002; Shank 2016; Warwick 2005). In this case, they become part of the experience through creating their own visual understanding and interpretation of a word's dictionary meaning and movement to help physically experience a letters shape and then to create the letter three dimensionally using clay (Burnett 2007; Cutcher 2013; Davis and Braun 1997, 2010; Silverman 2002; Shank 2016; Silverman and Freed n.d.; West 1997). 


\section{REFERENCES}

Ambrose, Patricia Philip, and Loh Sau Cheong. 2011. "Effects of the Clay Modeling Program on the Reading Behavior of Children with Dyslexia: A Malaysian Case Study." AsiaPacific EducationResearcher (De La Salle University Manila) 20 (3): 456-68.

Barber, Katherine. 2004. The Canadian Oxford Dictionary. Oxford: Oxford University Press.

Belbase, Shashidhar, Bal Chandra Luitel, and Peter Charles Taylor. 2008. "Autoethnography: A Method of Research and Teaching for Transformative Education." Online Submission.

Burnett, John. 2007. "A Pleasurable Path to Literacy: Can Steiner Contribute to the Literacy Debate?" Journal of Early Childhood Literacy 7 (3): 321-31.

Carson, Patricia, and Reesa Sorin. 2016. "Not Just Playing with Clay: Symbol Mastery for Spelling and Word Comprehension." International Journal of Learner Diversities and Identities 24 (1): 17-27.

Chang, Heewon. 2016. Autoethnography as Method, vol. 1. Abingdon, UK: Routledge.

Cope, Bill, and Mary Kalantzis. 2012. Literacies. Cambridge: Cambridge University Press.

Cutcher, Alexandra. 2013. "Art Spoken Here: Reggio Emilia for the Big Kids." International Journal of Art \& Design Education 32 (3): 318-30.

Davis, Ronald D., and Eldon M. Braun. 1997. The Gift of Dyslexia: Why Some of the Smartest People Can't Read and How They Can Learn, revised ed. New York: Berkley.

2010. The Gift of Dyslexia, Revised and Expanded: Why Some of the Smartest People Can't Read... and How They Can Learn. New York: Penguin.

Dewey, John. 1986. "Experience and Education." The Educational Forum 50 (3): 241-52.

Ellis, Carolyn, Tony E. Adams, and Arthur P. Bochner. 2011. "Autoethnography: An Overview." Historical Social Research/Historische Sozialforschung 12 (1): 273-90.

Fraser Institute. 2017. "Fraser Institute." Accessed July 6, 2018. https://www. fraserinstitute.org.

Graham, Steve, Paul Morphy, Karen R. Harris, Barbara Fink-Chorzempa, Bruce Saddler, Susan Moran, and Linda Mason. 2008. "Teaching Spelling in the Primary Grades: A National Survey of Instructional Practices and Adaptations." American Educational Research Journal 45 (3): 796-825.

Healy, Annah. 2008. Multiliteracies and Diversity in Education: New Pedagogies for Expanding Landscapes. South Melbourne: Oxford University Press.

Hertzog, Nancy B. 2007. "Transporting Pedagogy: Implementing the Project Approach in Two First Grade Classrooms." Journal of Advanced Academics 18 (4): 530-64.

Hill-Clarke, Kantaylieniere Y., and Nicole R. Robinson. 2002. "Locomotion and Literacy: Effective Strategies to Enhance Literacy Instruction." Paper presented at the 92nd Annual Meeting of the National Council of Teachers of English, Atlanta, Georgia, November 21-26, 2002.

Kentel, Adele, Jeanne, and Teresa Dobson, 2007. "Beyond Myopic Visions of Education: Revisiting Movement Literacy." Physical Education and Sport Pedagogy 12 (2): 145-62.

Kid Sense Child Development. n.d. "Kid Sense Child Development - Adelaide Occupational Therapy and Speech Pathology/Speech Therapy." Accessed July 6, 2018. https://childdevelopment.com.au.

Kuruyer, Hayriye Gül, Hayati Akyol, Kader Karli Oguz, and Arzu Ceylan Has. 2017. "The Effect of an Enrichment Reading Program on the Cognitive Processes and Neural Structures of Children Having Reading Difficulties." International Electronic Journal of Elementary Education 9 (4):809-28.

McNiff, Jean, and Jack Whitehead. 2011. All You Need to Know about Action Research. Thousand Oaks, CA: Sage Publications.

Neufedlt, V., ed. 1997. Webster's New World Children's Dictionary, 2nd ed. New York: Simon \& Schuster. 
Ngunjiri, Faith Wambura, Kathy-Ann C. Hernandez, and Heewon Chang. 2010. "Living Autoethnography: Connecting Life and Research.” Journal of Research Practice 6 (1): 115.

North Shore Pediatric Therapy. n.d. "Home." Accessed July 6, 2018. https://nspt4kids.com.

Nutbrown, Cathy. 2013. "Conceptualizing Arts-Based Learning in the Early Years." Research Papers Education 28 (2): 239-63.

Phillips, William E., and Jay Feng. 2012. "Methods for Sight Word Recognition in Kindergarten: Traditional Flashcard Method vs. Multisensory Approach.” Online Submission.

Rieg, Sue A., and Kelli R. Paquette. 2009. "Using Drama and Movement to Enhance English Language Learners' Literacy Development.” Journal of Instructional Psychology 36 (2): 148-54.

Roberts, Theresa A. 2003. "Effects of Alphabet-Letter Instruction on Young Children's Word Recognition.” Journal of Educational Psychology 95 (1): 41.

Sanders, J. Y., S. C. Parsons, M. Mwanita, and K. Thomas. 2015. "A Collaborative Autoethnography of Literacy: Professional Development Work in a High Needs Environment." Studying Teacher Education 11 (3): 228-45.

Shank, Monica. 2016. "Imagination, Waldorf, and Critical Literacies: Possibilities for Transformative Education in Mainstream Schools." Reading \& Writing-Journal of the Reading Association of South Africa 7 (2): 1-9.

Silverman, Linda Kreger. 2002. Upside-Down Brilliance: The Visual-Spatial Learner. Denver, CO: DeLeon Publishing.

Silverman, L. K., and J. N. Freed. n.d. Dyslexia the Gift. The Visual Spatial Learner. Accessed April 29, 2013. http://www.dyslexia.com/library/silver1.htm\#xzz29f8c.

Thompson, Mark E. 1982. "Creativity and the Reading Specialist: Some Observations from Research Data." Reading Horizons 23 (1): 1.

Tomascoff, Rocky N. 2004. "Fun \& Function with Clay." Arts \& Activities 135 (1): 36.

Treiman, Rebecca. 1993. Beginning to Spell: A Study of First-Grade Children. Oxford: Oxford University Press on Demand.

Treiman, Rebecca, and Kira Rodriguez. 1999. "Young Children Use Letter Names in Learning to Read Words." Psychological Science 10 (4): 334-8.

Wall, Sarah. 2006. "An Autoethnography on Learning about Autoethnography." International Journal of Qualitative Methods 5 (2): 146-60.

Warwick, Sharon. 2005. "The Science of Clay." School Arts: The Art Education Magazine for Teachers105 (3): 28-29.

West, Thomas G. 1991. In the Mind's Eye: Visual Thinkers, Gifted People with Learning Difficulties, Computer Images, and the Ironies of Creativity. Amherst, NY: Prometheus Books.

Woods, Krysta, Christina Janise McIntyre, Emily Reeves, and Pamela Whitehouse. 2018. "Integrating Movement in the Language Arts." In Moving INTO the Classroom, edited by Stacia C. Miller and Suzanne F. Lindt, 47-72. Singapore: Springer.

Woodard, Jennell. 2005. "Head, Heart and Hands: Waldorf Education." Journal of Curriculum and Pedagogy 2 (2): 84-85. 


\section{APPENDICES}

\section{Appendix 1-Kindergarten School Plans 2017/2018 (proposed)}

Table 1: Kindergarten School Plans 2017/2018 (proposed)

\begin{tabular}{|c|c|}
\hline & Activities/School Plan \\
\hline September & $\begin{array}{l}\text { - } \text { Pretest using Kindergarten Alphabet Assessments } \\
\text { - } \quad \text { Teach Release } \\
\text { - } \quad \text { Teach Focus } \\
\text { - } \quad \text { Teach Koosh ball exercises } \\
\text { - } \quad \text { Teach Dial setting } \\
\text { - } \quad \text { Explore the clay_roll, measure and shape (circle, square, triangle, rectangle) } \\
\text { - } \quad \text { Make animals and people out of clay }\end{array}$ \\
\hline October & $\begin{array}{l}\text { - Build upper case letters using the letter cards } \\
\text { - Look at different font styles }\end{array}$ \\
\hline November & $\begin{array}{l}\text { - } \quad \text { Continue making uppercase letters } \\
\text { - Using the alphabet strip to put letters in alphabetical order } \\
\text { - } \quad \text { Do alphabet mastery on upper case letters } \\
\text { - } \quad \text { Test uppercase letters by having student write them in alphabetical order }\end{array}$ \\
\hline December & - Continue review if needed \\
\hline January & $\begin{array}{l}\text { - } \text { Build lower case letters using the alphabet cards } \\
\text { - } \quad \text { Explore different font styles } \\
\text { eyes are tracking from left to right-for English. This is not for } \\
\text { comprehension). }\end{array}$ \\
\hline February & $\begin{array}{l}\text { - Using alphabet strip to put letters in alphabetical order } \\
\text { - } \quad \text { Do alphabet mastery on lower case letters } \\
\text { - } \quad \text { Test lower case letters by having them written them in alphabetical order } \\
\text { - } \quad \text { Cymbol Mastery on period, question mark, exclamation mark } \\
\text { sweep from left to right over a word and read it. If the word is not } \\
\text { recognized, spell reading is used. Punctuation is also read. This is not reading } \\
\text { for comprehension). }\end{array}$ \\
\hline March & $\begin{array}{l}\text { Do Create-a-Word to introduce the three parts of a word: Pronunciation, } \\
\text { spelling, and definition. } \\
\text { - } \quad \text { Symbol Mastery on a noun and verb. }\end{array}$ \\
\hline April-June & - Symbol Mastery with Basic Kindergarten Word List (See below). \\
\hline
\end{tabular}

\section{Basic Kindergarten Word List}

I, he, she, on, it, we, in, you, and, not 


\section{Appendix 2-Kindergarten School Plans 2017/2018 (carried out)}

\begin{tabular}{|c|c|}
\hline & Activities/School Plan \\
\hline $\begin{array}{l}\text { September } \\
2017 \text { to } \\
\text { February } 2018\end{array}$ & $\begin{array}{ll}\text { - } & \text { Teach Release } \\
\text { - } & \text { Teach Dial settings } \\
\text { - } & \text { Explore the clay }\end{array}$ \\
\hline $\begin{array}{l}\text { February to } \\
\text { April } 2018\end{array}$ & $\begin{array}{l}\text { - Selection of five learners to continue with program by teachers. } \\
\text { - Teach focus tool } \\
\text { - Teach Koosh-catching with one and two hands while standing on two feet } \\
\text { - Using letter templates make and master (Symbol Mastery) uppercase and } \\
\text { lowercase letters using letter names only } \\
\text { - Symbol Mastery on period }\end{array}$ \\
\hline $\begin{array}{l}\text { April to the } \\
\text { start of June } \\
2018\end{array}$ & $\begin{array}{l}\text { - Continue letter mastery with those that have not finished } \\
\text { - When finished the letters, do Symbol Mastery on the period } \\
\text { - } \quad \text { Create-a-Word and link to the three parts of a word } \\
\text { - } \quad \text { she, he) } \\
\text { - Introduce Spell (one or two sentences, minimum of three words) }\end{array}$ \\
\hline
\end{tabular}




\section{Appendix 3-Homeschoolers Plan 2017 September 2017}

Meet daily for an hour to an hour and a half.

Table 3: Homeschoolers Plan 2017 September 2017

\begin{tabular}{|c|c|}
\hline & Activities/School Plan \\
\hline Week One & $\begin{array}{l}\text { - } \quad \text { Introduce clay and allow time to explore } \\
\text { - } \quad \text { Teach Release and Dial } \\
\text { - } \quad \text { Take a personalized Dial } \\
\text { - } \quad \text { Introduce the idea of rolling the clay and cutting it to make different shapes } \\
\text { - } \quad \text { Clay sent home to practice with }\end{array}$ \\
\hline Week Two & $\begin{array}{l}\text { - Introduce-Koosh and catching with one Koosh at a time } \\
\text { Introduce letters and work through the first six together-child and } \\
\text { parent/guardian/support person at the end of the week give each family a set } \\
\text { of letter templates to be worked on at home }\end{array}$ \\
\hline Week Three & $\begin{array}{l}\text { - Have completed alphabet } \\
\text { Master punctuation: period. Older child can do other stop signs at home if } \\
\text { required. Go over with parents what they mean (Stop, breathe, and look at } \\
\text { picture made of what read) } \\
\text { - Demonstrate Spell Reading and send home with steps } \\
\text { - Do Create-a-Word and tie into three parts of the word (pronunciation, } \\
\text { spelling, and definition) } \\
\text { Introduce the idea of a dictionary } \\
\text { - Do Symbol Mastery on: table, tall, and run }\end{array}$ \\
\hline Week Three & 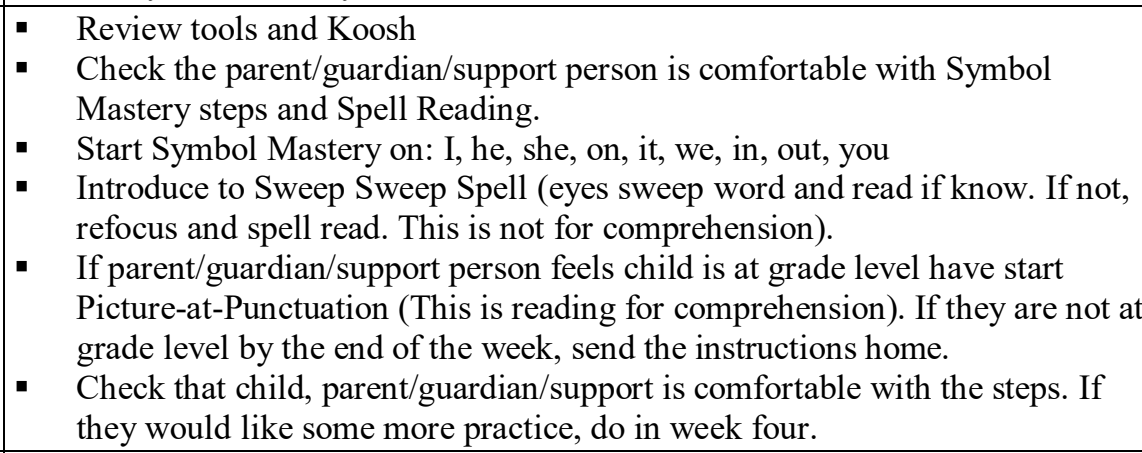 \\
\hline $\begin{array}{l}\text { Week Four } \\
\text { (if needed) }\end{array}$ & $\begin{array}{l}\text { - } \quad \text { Review all tools } \\
\text { Provide parent/guardian/support person with opportunities to ask questions } \\
\text { and practice skills not felt comfortable with. }\end{array}$ \\
\hline
\end{tabular}




\section{Appendix 4-Homeschoolers Plan 2017 (carried out)}

\section{September 2017}

Met three times a week for the first three weeks as per original plan. Not met until January (due to weather, other commitments, illness). Parent/guardian/support person provided with steps to reinforce tools, when to use them, clay, letter templates to continue to make the letters, and master. Also, some letter naming games they could use to reinforce knowledge, and two Koosh balls.

\section{January 2018}

Table 4: Homeschool Plan January 2018 (carried out)

\begin{tabular}{|c|c|}
\hline & Activities/School Plan \\
\hline Week One & $\begin{array}{l}\text { - First meeting-Go over tools and what had been doing with parents } \\
\text { (Children socialize) } \\
\text { - Second meeting-Introduce steps to Master Punctuation (As needed by the } \\
\text { child: period, comma, semicolon, dash, question mark, exclamation mark, } \\
\text { colon) }\end{array}$ \\
\hline $\begin{array}{l}\text { Week Two } \\
\text { until the } \\
\text { end of May }\end{array}$ & $\begin{array}{l}\text { - Met once a week for an hour and worked mainly with } \\
\text { parent/guardian/support person as children socialize. (Last three meetings } \\
\text { was with only child and parent.) This did not always work and met on an } \\
\text { average once every three weeks } \\
\text { - } \quad \text { Demonstrate Spell Reading and send home with steps } \\
\text { - } \quad \text { Do Create-a-Word and tie into three parts of the word (Pronunciation, } \\
\text { Spelling, and Definition) } \\
\text { - } \quad \text { Do Symbol Mastery on: table, tall and run, and send home with steps } \\
\text { - Start to do Symbol Mastery on: I, he, she (from Kindergarten word list) }\end{array}$ \\
\hline
\end{tabular}

Source: Data Adapted from Carson 2019.

\section{ABOUT THE AUTHOR}

Paddy Carson: Post-graduate Student, College of Arts, Society and Education, James Cook University, Cairns, Queensland, Australia 


\section{The International Journal of Early Childhood}

Learning is one of ten thematically focused journals in the collection of journals that support The Learner Research Network -its journals, book series,

conference, and online community.

The journal investigates the dynamics of learning in the first seven years of life.

As well as articles of a traditional scholarly type, this journal invites presentations of practice-including documentation of early childhood learning practices and exegeses of the effects of those practices.

The International Journal of Early Childhood Learning is a peer-reviewed, scholarly journal. 